\section{Modelling Climate-Sensitive Forest Succession to Assess Impacts of Climate Change and Support Decision Making}

GI_Forum 2021, Issue 2 Page: 65 - 81 Full Paper

Corresponding Author: simonalois@web.de

DOI: 10.1553/giscience2021_02_s65

\author{
Alois Simon 1,2 \\ 'University of Natural Resources and Life Sciences Vienna, Austria \\ 2Office of the Tyrolean government, Innsbruck, Austria
}

\begin{abstract}
Mountain forests provide a wide variety of ecosystem services to society. In light of the trend of temperature increase and related climatic extremes in the Greater Alpine Area, mountain forests are likely to undergo dramatic changes in the coming centuries. Therefore, forest managers face the challenge of adapting forests to support resilience to climate change. To facilitate this process, the forest gap model ForClim, a process-based forest succession model, was applied to generate site-specific information on future forest stand development and species composition. The tree species composition without management activities was predicted up to 2100 assuming a stable climate, and for both moderate and severe climate-change scenarios. Furthermore, three different forest stand development scenarios were implemented. The forest stand investigated in our research shows significant climate-sensitivity. Results demonstrate that deciduous mixed forest stands are necessary to increase resilience and manage forests for climate change. Using active silvicultural measures, such as assisted migration through planting thermophilus species, negative effects of climate change could be reduced. The modelling approach presented here is appropriate for assessing the impacts of climate change and supporting decision making by local forest managers.
\end{abstract}

\title{
Keywords:
}

dynamic vegetation model, mountain forest, long-term development, tree species composition, Austria

\section{Introduction}

Predicting forest growth and stock volume is an age-old task in forestry science, going back to the first yield tables in the 19th century, e.g. Hartig (1847); Lorey (1878); Weisse (1880); Schwappach (1890). With these early attempts to quantify forest productivity, the foundations for sustainable management of natural resources were laid. Static yield tables for single-species, evenly-aged forest stands (Assmann \& Franz, 1963) are still widely used. However, the high proportion of mixed-species, unevenly-aged, structurally diverse forest stands in mountain areas have always hampered their implementation in mountain forests. Besides static yield 
tables, dynamic models for predicting forest growth were also developed and gained increasing popularity (Röhle, 2004). The general shift in forestry towards mixed-species forests (BFW, 2019), and the fact of heterogeneous and non-static environmental conditions, enhanced the demand for dynamic growth models for forest management.

In addition to sustainable timber production (BMNT, 2018), mountain forests provide a wide variety of ecosystem services, e.g. prevention of natural hazards (Berger et al., 2013), recreation, welfare (Forest Act, 1975) and carbon storage (Prietzel \& Christophel, 2014). In view of the trend of temperature increase and related climatic extremes in the Greater Alpine Area (Auer et al., 2014), and the continuously increasing global carbon emissions (Le Quéré et al., 2018), mountain forests are likely to undergo dramatic changes in the coming centuries (Allen et al., 2010). Therefore, forest managers face the challenge of adapting forests and supporting resilience to climate change (Rasche et al., 2011). To facilitate this process, dynamic vegetation models can generate site-specific information on future forest stand development and species composition (Seidl et al., 2011). Alongside process-based models, correlative species distribution models (Guisan et al., 2017) are widely used; an overview of the applications in forest management is given by Pecchi et al. (2019).

The development of decision support systems in forest management is reviewed by Vacik and Lexer (2014), who identified the main challenge as balancing ease-of-use and model complexity due to users' growing information demands. As well as applications in practical management, model-based decision support also has the potential to be used in forest policy-making (Linkevičius et al., 2019).

As year-round settlements in mountain areas are primarily located at lower elevations, public demands on lower-altitude forests are especially high. Predictions of climate change impacts (Remund \& Augustin, 2015) and forest disturbances in recent decades (e.g. Bigler et al. (2006); Jump et al. (2006)) suggest that forests at lower elevations are especially susceptible. Hence, investigating the impacts of climate scenarios at drought-prone low-elevation sites is crucial for forest management.

By applying a process-based, climate-sensitive forest succession model, this study investigates future tree species composition and growth at sites that may be critically affected by drought stress under climate change. To guarantee the transferability of the approach and to increase its usability, open-source products was used in designing the workflow. Demonstrating the expected change in tree species composition will support decision making in the context of adaptations for climate change.

\section{Material and Methods}

\subsection{Study site and data recording}

The forest investigated is located in the valley of the river Inn in the province of Tyrol, Austria (Figure 1). The study site is at an elevation of $670 \mathrm{~m}$ asl and has a steep $\left(30^{\circ}\right)$, south-west facing $\left(200^{\circ}\right)$ slope. The average annual rainfall is c. $1160 \mathrm{~mm}$, and the annual mean temperature c. $8.1^{\circ} \mathrm{C}$ (ZAMG, 2015). The geological bedrock material consists of calcareous, coarse, fluvial 
sediments which develop to a mosaic of Renzic Leptosols and Calcareous Cambisols (IUSS Working Group WRB, 2014). The potential natural vegetation type of the study site is classified as forest dominated by European beech (Fagus sylvatica (L.), ranging from Carici albaeFagetum on the slightly drier ridge and the upper slope, to Mercuriali-Fagetum caricetosum albae from mid-slope down to the bottom of the slope (Forest Site Classification Tyrol, 2018). The forest stand is dominated by Scots pine (Pinus sylvestris (L.)) and Norway spruce (Picea abies ((L.) Karts)). In the understorey, P. abies dominates, with occasional common oak (Quercus robur (L.)) and F. sylvatica. The only occurring black pine (Pinus nigra (J.F.Arnold)) is combined with P. sylvestris for further analysis.

A plot of $10,000 \mathrm{~m}^{2}(180 \times 55 \mathrm{~m})$ was marked out at the study site; each tree above $7 \mathrm{~cm}$ in diameter at breast hight (DBH) was recorded, and along with its $\mathrm{DBH}(\mathrm{cm})$, its height $(\mathrm{m})$ and $\mathrm{x}-\mathrm{y}$ location were also noted. To describe the soil properties, two soil profiles were excavated, described according to the Austrian soil classification (Nestroy et al., 2011) a plant-available water storage capacity of $85 \mathrm{dm}^{3 *} \mathrm{~m}-2$ was calculated according to Arbeitskreis Standortskartierung (2003). The $60 \mathrm{~kg} *$ ha-1 nitrogen stock available for plant growth was estimated to be $2 \%$ of the total nitrogen in the soil (Blume et al., 2009), based on the analysis of soil-profile data with comparable bedrock material (Simon et al., 2021).

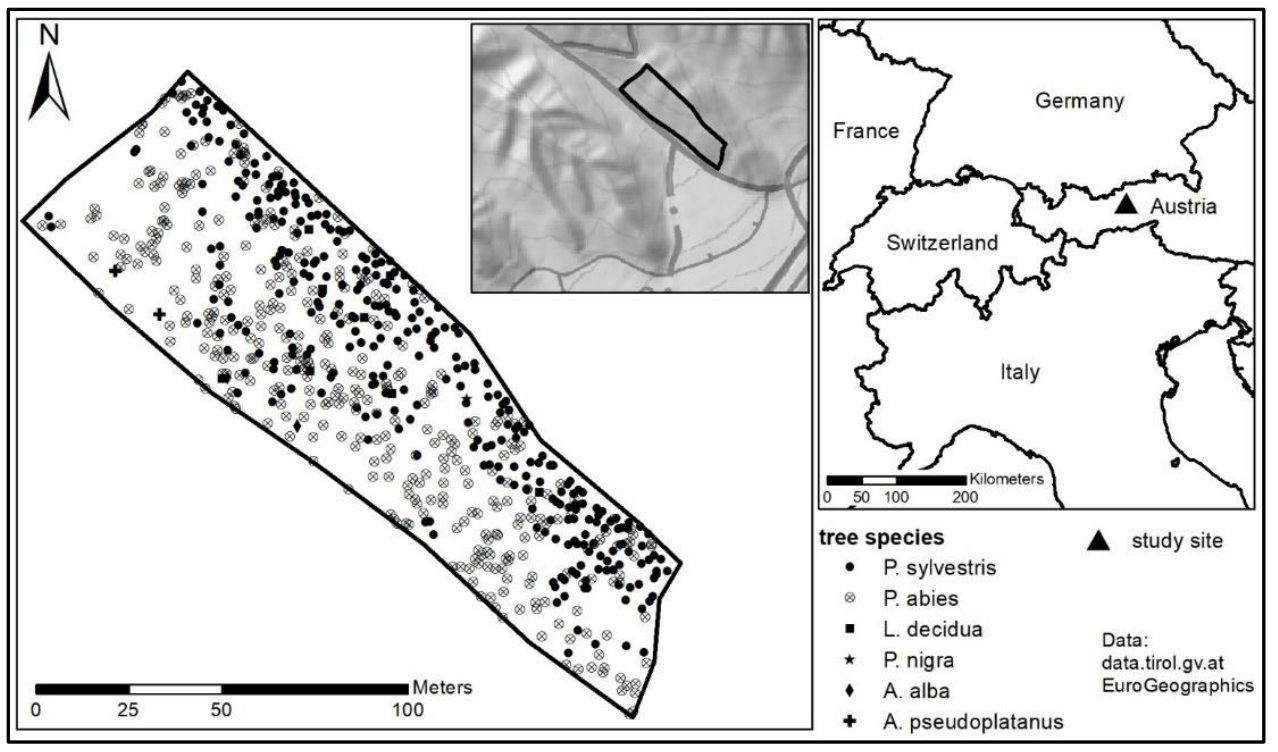

Figure 1: Location of the study site and current tree-species distribution of the forest stand.

\subsection{Dynamic forest model}

To model the future tree species composition, the tried and tested forest gap model ForClim (Bugmann, 1996), developed by the Forest Ecology Group of ETH Zurich, was used. Forest gap models in general are widely used by forest ecologists to address a large number of applied research questions. In these models, forests are represented as a composite of many small patches of the same size, usually defined by the crown size of an adult tree. Each patch can be 
of a different age and successional stage, and is horizontally homogeneous; exact tree position within the patch is not taken into account. All patches have the same resource level, and patches do not interact with each other. Tree establishment, growth and mortality are modelled for each patch individually (Bugmann, 2001).

ForClim Vers. 4.0.1 (Huber, 2019) consists of four submodels, namely WEATHER, PLANT, WATER and MANAGEMENT. The present study considers only the first three of these. The PLANT submodel was initialized using data for the current forest stands (Figure 1). By default, 30 tree species are parametrized for central Europe (Huber, 2019). Of these, the tree species that are currently found at the site and a set of naturally occurring tree species (Forest Site Classification Tyrol, 2018) were selected for modelling. For the current forest stand, a patch size of $400 \mathrm{~m}^{2}$ was selected with which to initialize the model. Due to the irregular shape of the forest stand (Figure 1), the total area was divided into just 24 patches $\left(9,600 \mathrm{~m}^{2}\right)$. In order to upscale to the recommended 200 modelling patches (Forest Ecology Group, 2019), representing an area of $8 \mathrm{ha}$, the patches were repeated, each eight times, to which were added eight randomly selected patches. To account for the regeneration of trees between $1 \mathrm{~cm} \mathrm{DBH}$ and the recording threshold of $7 \mathrm{~cm} \mathrm{DBH}$, individuals were added to the patches based on field estimations.

The input data for the WEATHER (Table 1) and WATER submodels are derived from the recorded site data and climatic data. The general model variant '24' was implemented (Huber et al., 2020) to define the regeneration routine, the allocation of growth to height and diameter, and the background mortality (Forest Ecology Group, 2019). This variant reduces the strong differences between shade-tolerant and shade-intolerant species through recruitment limitation of shade-tolerant species (E6*) and growth allocation (A2). These assumptions are in line with empirical findings on regeneration patterns of the shade-tolerant species Fagus sylvatica and Abies alba (Nagel et al., 2010). The background mortality (M1) of this model variant is described as a u-shaped relationship between DBH and mortality probability. This relationship represents high mortality in the early life-stages of saplings, and increased mortality of mature trees (Monserud \& Sterba, 1999).

\subsection{Simulation scenarios and climate data}

Tree species composition was predicted in annual timesteps from 2020 to 2100. Three different climate scenarios were applied for the simulation: a stable climate with an extrapolation of the current climate (A) (data for 1 January 1981 to 31 December 2010); a moderate climate-change scenario (B), and a severe climate-change scenario $(\mathrm{C})$, represented by Representative Concentration Pathways (RCPs) of 4.5 and 8.5 (IPCC, 2014) for B and C respectively. Since the different RCPs do not start to show greater differentiations before 2050 (IPCC, 2014), two timesteps were implemented for the climate-change scenarios (Figure 2). These time steps were 1 January 2020 to 31 December 2070, and 1 January 2071 to 31 December 2100. All necessary climate data (Table 1) were selected from the ÖKS15 datasets (ÖKS15, 2016) with a 1x1 km spatial resolution, provided by the Climate Change Centre Austria (data.CCCA). The reference period of these datasets is 1961-2005, with a temporal resolution of 24h. The data are generated by the EURO-CORDEX model 'cnrm-cerfacscnrm-cm5' using the 'r1i1p1' ensemble; they are corrected for bias (in scaled distribution mapping) using observations from Spartacus or GPARD (ZAMG, 2015). The climate data 
used in scenario A give a mean annual temperature (MAT) of $9.2^{\circ} \mathrm{C}$ and a mean annual precipitation (MAP) of 1,127 dm $\mathrm{dm}^{3 *} \mathrm{~m}-2$ for the period 1981-2010. These serve as a baseline in the model. The MAP is thus similar to the $1,079 \mathrm{dm}^{3 *} \mathrm{~m}-2$ given by the 3 PClim dataset (ZAMG, 2015); for the MAT, the same data source gives slightly cooler conditions, of $8.6^{\circ} \mathrm{C}$. For scenario A, monthly data is used; for scenarios B and C, only seasonal data are needed (Table 1) by ForClim. For the last decade of the modelling period, Scenario B (for moderate climate change) shows a MAT increase of $1.7^{\circ} \mathrm{C}$, and scenario $\mathrm{C}$ (for severe climate change) shows a MAT increase of $3.5^{\circ} \mathrm{C}$ (see Figure 2). The MAT thus increases progressively from the start of the modelling period. For precipitation, the climate scenarios show a slight increase, of around $1-4 \%$, especially during winter.

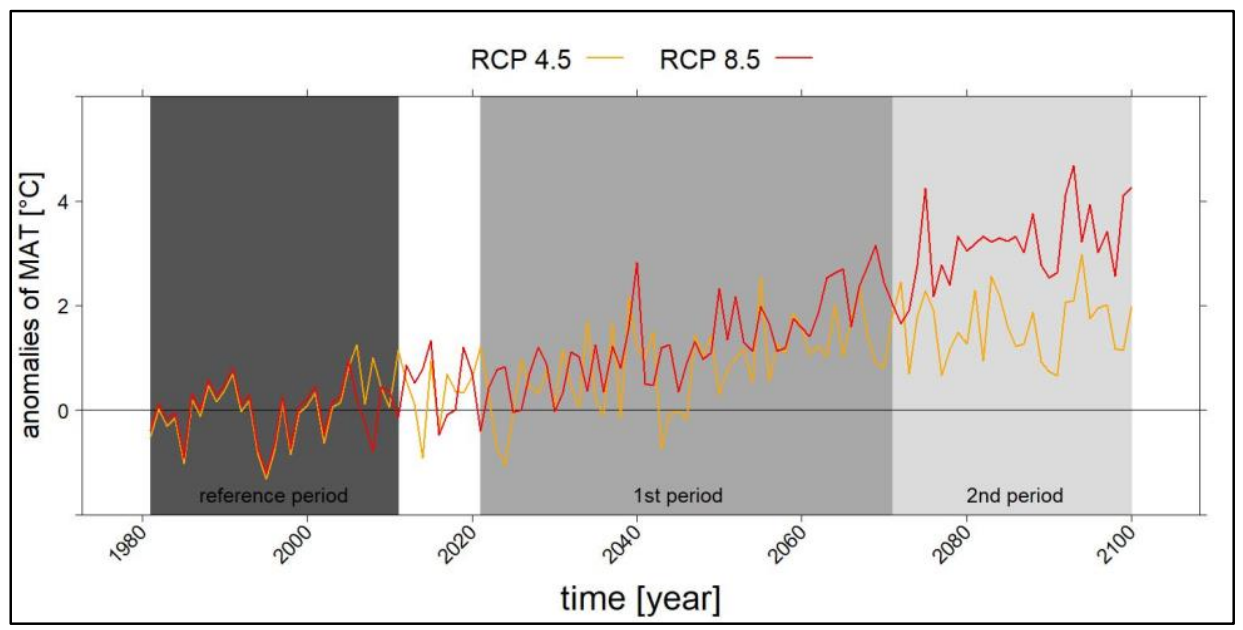

Figure 2: Predicted changes of Mean Annual Temperature (MAT) for the climate-change scenarios. The baseline is the MAT for 1981-2010.

Based on the current stand data, three different forest stand development scenarios were developed for the simulation: a business-as-usual scenario (I), allowing only currently-present species to grow and regenerate; a mixed species scenario (II), allowing for migration of species through natural regeneration; and a mixed species scenario with assisted migration (III) in which the best-performing species of scenario II are planted at the beginning of the modelling period. The trees planted in scenario III are considered to have a DBH of $1 \mathrm{~cm}$ and height of $150 \mathrm{~cm}$; they are added to the present forest stand. The species for planting in scenario III are chosen from among those with the best performance in the mixed species scenario (II); how many were planted and the proportions of different species are based on the current forest stand structure and the silvicultural requirements of the species selected. In the present case, 400 Quercus petraea and 200 Tilia cordata saplings*ha-1 were planted at the beginning of the modelling period. This corresponds to 3 groups of 8 saplings for each patch $\left(400 \mathrm{~m}^{2}\right)(2$ groups of Q. petraea, and one 1 of T. cordata), or a total of 75 groups*ha-1, 50 of which were comprised of $\mathrm{Q}$. petraea, and 25 of $\mathrm{T}$. cordata. 
Table 1: Climate data for ForClim simulation scenarios, with data sources.

\begin{tabular}{|c|c|}
\hline variable & data source \\
\hline \multicolumn{2}{|l|}{$\begin{array}{l}\text { current climate (A) } \\
\text { (Jan, Feb, Mar, Apr, May, Jun, Jul, Aug, Sep, Oct, Nov, Dec) }\end{array}$} \\
\hline $\begin{array}{l}\text { monthly mean temperature (mT) } \\
\text { monthly temperature standard deviation ( } \mathrm{sdT}) \\
\text { monthly mean precipitation (mP) } \\
\text { monthly precipitation standard deviation ( } \mathrm{sdP}) \\
\text { monthly temperature-precipitation cross-correlation (rTP) }\end{array}$ & $\begin{array}{l}\text { https://hdl.handle.net/20.500.11 } \\
\underline{756 / 1 \mathrm{dba} 52 \mathrm{~b} 2} \\
\underline{\text { https://hdl.handle.net/20.500.11 }} \\
\underline{\text { calculated from } \mathrm{mT} \text { and } \mathrm{mP}}\end{array}$ \\
\hline $\begin{array}{l}\text { climate change RCP } 4.5 \text { (B) } \\
\text { (Spring: Mar, Apr, May; Summer: Jun, Jul, Aug; Autumn: Sep, }\end{array}$ & Oct, Nov; Winter: Dec, Jan, Feb) \\
\hline $\begin{array}{l}\text { seasonal mean temperature (CC_mT) } \\
\text { seasonal temperature standard deviation (CC_sdT) } \\
\text { seasonal mean precipitation (CC_mP) } \\
\text { seasonal precipitation standard deviation (CC_sdP) } \\
\text { seasonal temperature-precipitation cross-correlation } \\
\left(C_{-} \text {_rTP) }\right.\end{array}$ & $\begin{array}{l}\text { https://hdl.handle.net/20.500.11 } \\
\underline{756 / 9 d f 12611} \\
\text { calculated from CC_mT and CC_mP }\end{array}$ \\
\hline $\begin{array}{l}\text { climate change RCP } 8.5 \text { (C) } \\
\text { (Spring: Mar, Apr, May; Summer: Jun, Jul, Aug; Autumn: Sep, }\end{array}$ & Oct, Nov; Winter: Dec, Jan, Feb) \\
\hline $\begin{array}{l}\text { seasonal mean temperature (CC_mT) } \\
\text { seasonal temperature standard deviation (CC_sdT) } \\
\text { seasonal mean precipitation (CC_mP) } \\
\text { seasonal precipitation standard deviation (CC_sdP) } \\
\text { seasonal temperature-precipitation cross-correlation } \\
\text { (CC_rTP) }\end{array}$ & $\underline{\text { https://hdl.handle.net/20.500.11 }}$ \\
\hline
\end{tabular}

\subsection{Data processing and modelling}

The data and output processing as well as the model runs were performed using the statistical software R (R Core Team, 2019). The climate data (Table 1) were accessed in netCDF format using the R package ncdf4 (Pierce, 2017). The transformation of the climate and stand data into XML structure for the ForClim model input was carried out using the R package XML (Duncan, 2020). To capture stochastic processes (e.g. recruitment, mortality) in the model, each model run was repeated 100 times, changing the seed of the random generator (seedValue) in the ForClim setup file. The upscaling of the present forest stand was repeated 100 times to test for random effects in the model initialization. The aggregation of the multiple iterations was carried out using R package matrixStats (Bengtsson, 2020). For graphical output, the R package lattice (Sarkar, 2008) was used. The modelling workflow was documented using a business process model and notation (see the supplements). 


\section{Results}

\subsection{Growth patterns of individual species}

For the prediction of the tree species composition, the following species from the present forest stand were selected: Silver fir (Abies alba (Mill.)), sycamore maple (Acer pseudoplatanus (L.)), European larch (Larix decidua (Mill.)), Norway spruce (Picea abies) and Scots pine (Pinus sylvestris) (Figure 1); also selected were: European beech (Fagus sylvatica) and common oak (Quercus robur), which were occasionally present in the regeneration; sessile oak (Quercus petraea ((Matt.) Liebl.)), small-leaved lime (Tilia cordata (Mill.)), and large-leaved lime (Tilia platyphyllos (Scop.)) as thermophilus trees of lower elevations; and silver birch (Betual pendula (Roth)) and whitebeam (Sorbus aria (Crantz)) as typical pioneer species. The predicted tree species composition is characterized by the total volume $\left[\mathrm{m}^{3 *} \mathrm{ha}^{-1}\right]$, which describes the stock of the forest stand. The temporal response pattern of the growth parameters for the mixed species scenario with natural regeneration (scenario II) under different climate conditions is illustrated in Figure 3. Of the tree species investigated that are not currently present in the forest stand, Q. petraea and T. cordata showed the best growing performance in terms of volume increment (Figure 3). Replacing Q. robur by Q. petraea in the model showed that the latter performed significantly better than the former. The same was true for the two lime species: T. cordata was superior to T. platyphyllos. The pioneer species are not shown in Figure 3 as they reach only very low values in all climate scenarios, with a maximum of $0.16 \mathrm{~m}^{3 *} \mathrm{ha}^{-1}$ under the current climate scenario. All tree species currently present in the forest stand (Figure 1) showed a reduction in volume under the severe climate-change scenario (RCP 8.5, Figure 3C) compared to the current climate (Figure $3 \mathrm{~A}$ ) up to the end of the prediction period. Even under the moderate climate-change scenario (RCP 4.5, Figure 3B), a negative trend is observed for $L$. decidua and above all for $P$. abies, which is the only species that already shows a negative trend under current climate conditions. The decline of $P$. abies shows a very low standard deviation over the whole modelling period. P. sylvestris turned out to be the most resilient species at the site, increasing its share significantly under all climate scenarios. It is only at the end of the modelling period that it shows a slight decline in volume for all climate scenarios.

\subsection{Growth patterns of stand development scenarios}

The development of the growing stock under the three different stand development scenarios is illustrated in Figure 4. For the tree species currently present and their natural regeneration (I), a decrease of volume is predicted for climate-change scenarios B and C compared to the growth pattern under current climate conditions. For the last decade (2090-2100), for the moderate and severe climate-change scenarios, the mean decreases are $2.9 \pm 31.8$ and $21.9 \pm$ $29.7 \mathrm{~m}^{3 *} \mathrm{ha}^{-1}$ ( \pm standard deviation) respectively. The second stand development scenario (Figure 4, II), which allows for the natural regeneration of mixed species, was developed from the results of the individual species' performances (Figure 3). The increasing volume, especially of Q. petraea and T. cordata and to a certain extent of F. sylvatica (Figure 3), counteracts the negative development of the climate-change scenarios. For the RCP 8.5 scenario, a decrease of $3.8 \pm 33.7 \mathrm{~m}^{3 *} \mathrm{ha}^{-1}$ is predicted for the last decade; for the current climate and for the RCP 4.5 scenario, increases of $14.0 \pm 30.5$ and $12.4 \pm 29.3 \mathrm{~m}^{3 *} \mathrm{ha}^{-1}$ (mean \pm standard deviation) are 
predicted for the last decade. The third stand development scenario, with planting at the beginning of the modelling period, leads to an increase in stock for all climate scenarios (Figure 4 , III) compared to the baseline. The increases for the last modelling decade (mean \pm standard deviation) are as follows. For the current climate: $61.0 \pm 36.0$; for the moderate climate-change scenario (RCP 4.5): $59.8 \pm 31.4$; for the severe climate-change scenario (RCP 8.5): $37.2 \pm 36.7$ $\mathrm{m}^{3 *} \mathrm{ha}^{-1}$.

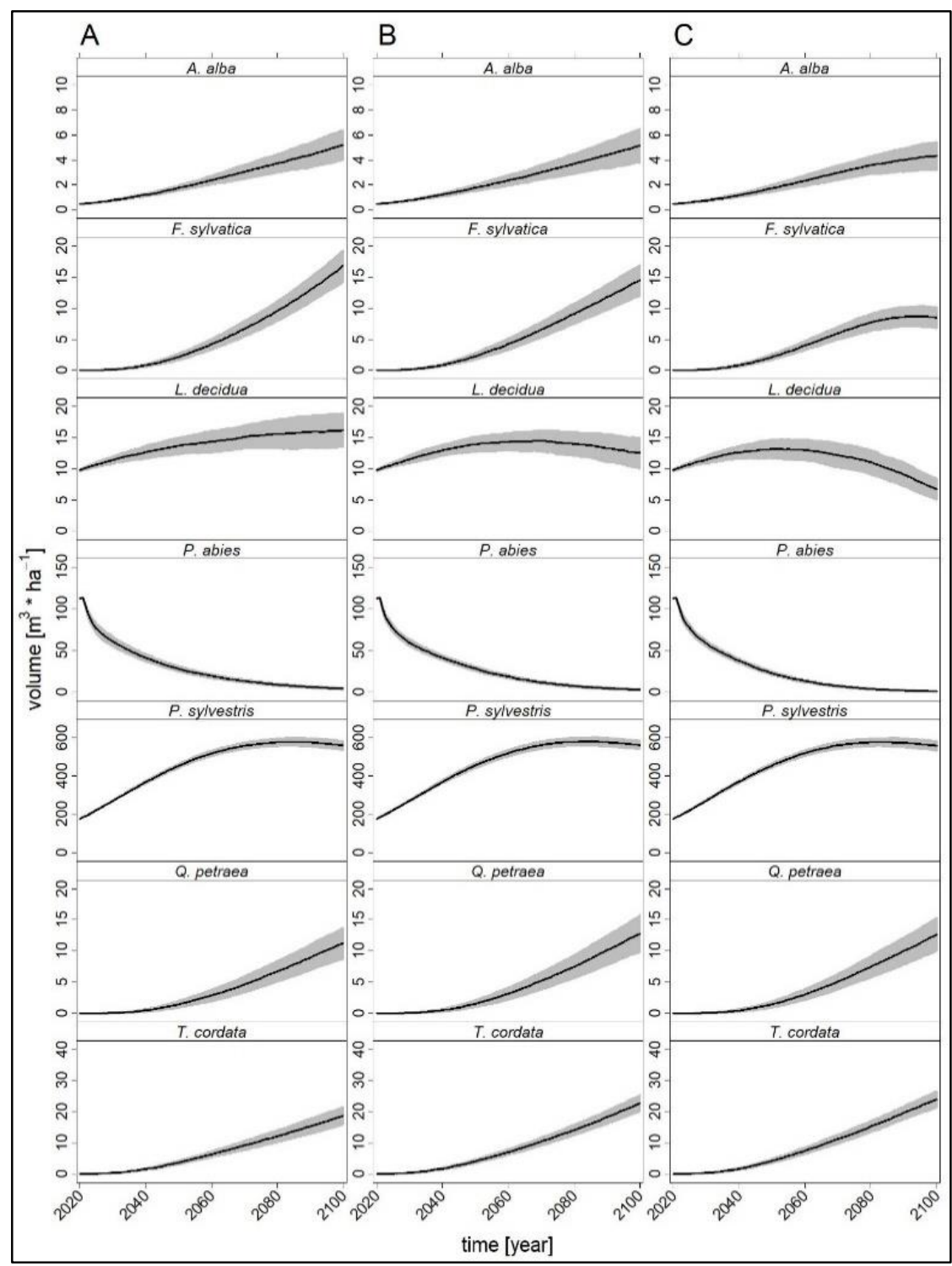

Figure 3: Predicted tree species composition of the mixed-species regeneration scenario (II) for the study site under different climate scenarios. A: current climate, B: moderate climate-change scenario (RCP 4.5), C: severe climate-change scenario (RCP 8.5); black line: mean of 100 model runs; shaded area: standard deviation of 100 model runs. 


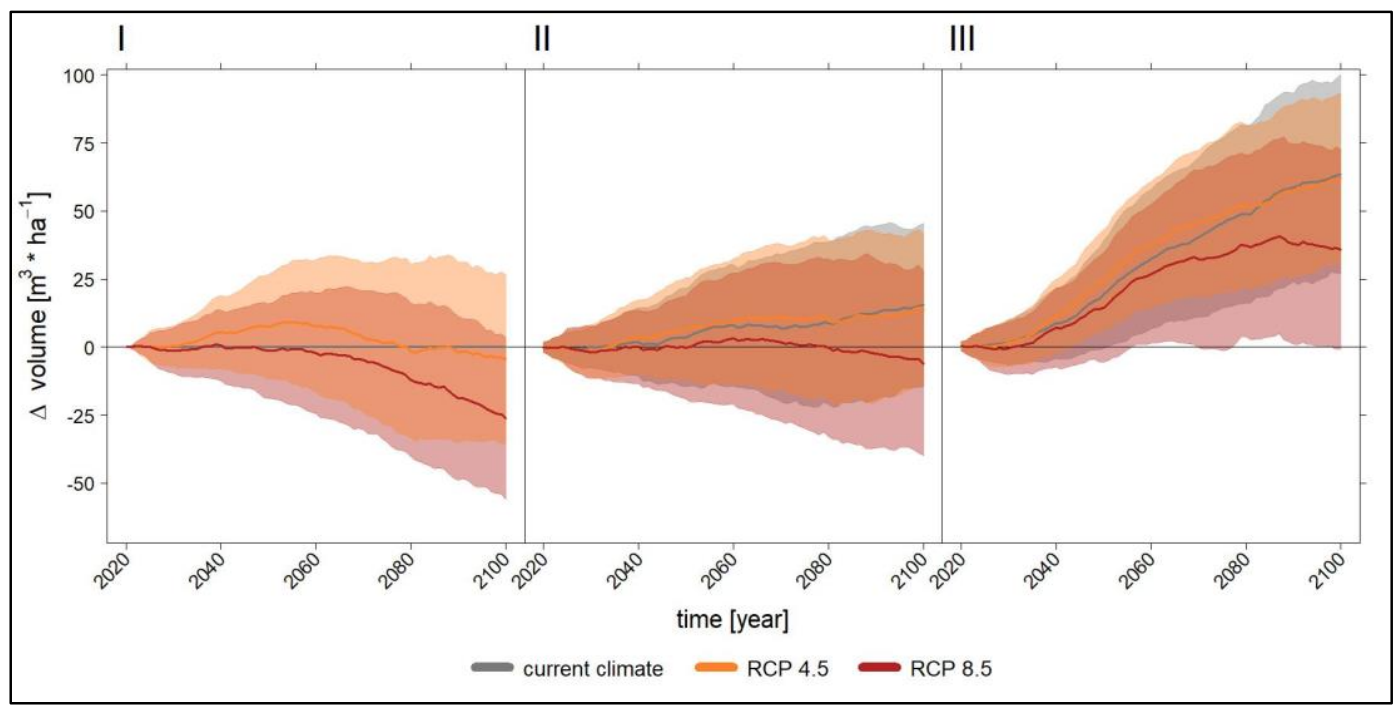

Figure 4: Change in growing stock for different stand development and climate scenarios in relation to the predictions for stand development scenario I under current climate scenario (A). I: present species regeneration only; II: mixed species regeneration; III: mixed species regeneration and planting. Solid line: mean of 100 model runs; shaded area: standard deviation of 100 model runs for current climate (grey), RCP 4.5 (light orange), and RCP 8.5 (light red).

\section{Results}

\subsection{Methodological considerations}

In this study, the dynamic forest succession was modelled up to the end of the twenty-first century. The forest stand responses are driven by the establishment, growth and mortality of individual trees related to climate scenarios (e.g. length of growing season) or soil moisture (Forest Ecology Group, 2019). The effects of forest disease (Sturrock et al., 2011) or outbreaks of bark beetle or defoliating insects are not considered in the modelling approach presented here, although these disturbance agents can change the competitive relationship between species and the pathways of stand development quite dramatically (Seidl et al., 2017).

Furthermore, the parametrization of the For Clim model for the tree species characteristics does not contain intraspecific variation resulting from different tree provenances, although these can modify the response to extreme climatic events (Wang et al., 2020). However, more detailed parametrization would not be beneficial if the origin of the forest stand under investigation is unknown, as in the majority of forest stands. A trade-off between general validity and specialization is ubiquitous in dynamic vegetation models and many other modelling approaches. A recent evaluation of various forest ecosystem models that use longterm inventory data (Irauschek et al., 2021) evidenced ForClim's suitability for stand development projections. To assess the impacts of climate change, raise awareness and support decision making, predicting general growth patterns of species and forest stands is considered perfectly adequate. 
As reproducibility in research is also an increasingly important topic in geographic information science (Nüst et al., 2018), the modelling workflow was implemented using Free/Libre and Open Source Software (FLOSS). This should guarantee the transferability of the application and increase its usability.

As the mean and standard deviation of 100 iterations of the model runs are shown, the change in species composition and growth seem to be gradual, rather than abrupt, after the disturbance of stands or removal of single species. Although the prediction uncertainty is high, extreme climatic events, like heatwaves and droughts, will shape forest ecosystems to a greater extent than gradual changes in average conditions (Fuhrer et al., 2006). Such tipping-point dynamics, resulting in sudden drought-related tree mortality, become very likely with progressing climate change (Allen et al., 2015). Therefore, non-linear responses of ecosystems should also be considered in the management recommendation.

\subsection{Species-specific growth patterns}

Although the trajectories of temperature changes (Figure 2) show relatively small differences between the emission scenarios (RCP 4.5 and 8.5) for the first half of the century (IPCC, 2014), the impacts on the species differ. The growth responses intensify as time goes on, and at the end of the century clear trends in species-specific growth patterns can be identified.

The most notable development was for Picea abies, which shows a strong reduction in volume under all climate scenarios (Figure $3 \mathrm{~A}-\mathrm{C}$ ). The low standard deviation of this growth patterns indicates a high correspondence between all model runs. It is predicted that $P$. abies will be almost absent from the site by the end of the century. In the face of the extensive dieback of P. abies at lower elevations of Central Europe, initiated by the drought in 2018 (Krejza et al., 2020), a strong decline is likely. As P. abies was for a long time planted far beyond its natural distribution range (Spiecker, 2000), it also occurs at marginal sites where a general withdrawal is observed (BFW, 2019). P. abies seems to be at high risk in the study site, in terms of its resilience and adaptation to climate change, as well as in terms of sustainable timber production and provision of ecosystem services.

The temporal pattern for volume growth of Larix decidua was not as clear as for P. abies, but it did show a slightly negative trend up to 2070, which strengthened over time (Figure 3, B and C). This is interpreted as the high climate-sensitivity of $L$. decidua at the study site. The response of $L$. decidua to drought and therefore its silvicultural suitability under climate change need to be studied more closely. The results are in line with the findings of Lévesque et al. (2013), who reported growth reduction of $L$. decidua for a mesic lowland site in Switzerland, and a xeric, mid-elevation, inner-alpine site in Italy. The same response was observed by Obojes et al. (2018) investigating the radial growth of $L$. decidua in mid-elevation to high-elevation forests in another xeric inner-alpine valley in Italy. Accordingly, these findings might also be valid for drought-prone mountain forests at lower elevations in the transition zone between the Atlantic- or Mediterranean-influenced fringes of the Alps and the continental inner-alpine areas.

A typical tree species for this transition zone is Fagus sylvatica, which is highly competitive in the lowlands of Central Europe and the fringes of the Alps, but is known to be droughtsensitive (Leuschner, 2020). Thus, F. sylvatica shows an increase in volume under the current 
climate scenario (Figure 3A), but this trend weakens already under the moderate climatechange scenario (Figure 3B). Furthermore, in the severe climate-change scenario (Figure 3C), a significant reduction in growth from 2080 onwards is predicted. Given the negative impact of the 2018 drought on F. sylvatica (Schuldt et al., 2020), the predicted growth pattern could be ascribed to climate change-related heatwaves and drought periods.

For Abies alba, most of the increase in volume relates to the growth of the two existing juvenile individuals at the study site; results should therefore not be overinterpreted. Nevertheless, in contradiction to the findings of Thurm et al. (2020), A. alba seems to be more resilient than $L$. decidua to climate change (Figure 3, B and C).

The only species of conifer tree with an increasing growth pattern is Pinus sylvestris, which is known to be highly drought-tolerant (Krakau et al., 2013). In the present forest stand, it is the dominant tree species and has an almost normal distribution of DBH classes, up to a maximum of $25-30 \mathrm{~cm}$. The stock at the beginning of the modelling period is only $200 \mathrm{~m}^{3 *} \mathrm{ha}^{-1}$. This is predicted to almost triple by the end of the century, regardless of the climate scenario (Figure $3, \mathrm{~A}-\mathrm{C})$. On the one hand, this is a result of the present forest structure, with low stock and a favourable DBH distribution of $P$. sylvestris, a structure which generally allows high annual increments. Compared with the recommended yield tables for P. sylvestris in Tyrol (Eckmüllner, 2004), the predicted growth in volume is at the upper end of the range, but possible at sites with favourable conditions. On the other hand, P. sylvestris seems to suffer fewer adverse effects from climate change than other species, as there are no significant differences between the scenarios. Rather, P. sylvestris could benefit from the decline of other competing species, such as $P$. abies and $L$. decidua, and improved access to resources. Nevertheless, the predicted growth of $P$. sylvestris seems to be overestimated as site conditions are not among the best regarding increased growth. This is also evidenced by an average age of $P$. sylvestris above $20 \mathrm{~cm} \mathrm{DBH}$ of around 110 years, which indicates a generally low growth rate and age-related flattening of it (Eckmüllner, 2004). As current age is not considered in the model initialization, this could lead to misjudgement of the growth pattern. Regardless of the exact stock, it continues to be an important species and ensures continuity of the forest cover at the sites studied.

The thermophilus deciduous tree species Quercus petraea and Tilia cordata, which are both absent from the present forest stand, proved to be highly suitable under all climate scenarios (Figure $3, \mathrm{~A}-\mathrm{C})$. A comparison of the two sympatric oak species demonstrated the superiority of $Q$. petraea over Q. robur with the increasing severity of the climate scenario. Differences between these two oak species are also reflected in the findings of Vivin et al. (1993), who showed that the shoot growth of $Q$. petraea is less sensitive to water deficit than the shoot growth of $Q$. robur. Ponton et al. (2002) summarized that the lower growth rate of $Q$. petraea compared to $Q$. robur is associated with the greater long-term survival of adult $Q$. petraea trees in drought-prone environments. While literature on the direct comparison of the drought tolerance of $T$. cordata and T. platyphyllos is scarce, Hölscher et al. (2005) confirmed a high drought tolerance of $T$. cordata, which has a distribution range far beyond that of T. platyphyllos: it extends into the continental zone of Europe, which has regular or episodic summer drought. According to the findings presented here, Q. petraea and T. cordata form an important basis for building climatesmart forests; they are predestined for stand development scenario (III), in which the bestperforming species from the mixed-species scenario are planted at the beginning of the modelling period. 


\subsection{Change patterns in the development of stands}

The modelling results of the current climate scenario showed a discrepancy between those trees actually present and the natural tree species composition in the forest stand investigated. The predicted increase of F. sylvatica (Figure 3A), under the elimination of seed limitation, is in line with dry beech forest having been classified as potential natural vegetation (Forest Site Classification Tyrol, 2018). Likewise, more thermophilic deciduous trees (e.g. oak, lime) are already feasible under current climate conditions. Nevertheless, the observed growth potential of F. sylvatica is weakening (Figure 3, B and C), and thus the potential natural vegetation type may also change. Considering the high growth potential of thermophilus oak and lime species at the site, a shift towards an oak-dominated mixed forest is likely. The reasons for the present dominance of $P$. sylvestris and $P$. abies and the absence of deciduous trees could be numerous, ranging from effects of historical forest use (e.g. forest pasture, litter removal, clear-cuts), high browsing pressure preventing regeneration of deciduous trees, to the silvicultural objectives or preferences of the forest owner.

In all stand development scenarios (Figure 4, I-III), growth increases until around 2080 for the moderate climate-change scenario (scenario B, RCP 4.5), and then falls below the stocks predicted under current climate conditions (scenario A). This indicates that the current growth conditions are slightly temperature-limited, and a moderate temperature increase can foster tree growth, e.g. through an extension of the growing period. In addition, the severe climatechange scenario (scenario C, RCP 8.5) showed the lowest stock development in all cases. Especially in the $2^{\text {nd }}$ time period (2071-2100) (Figure 2), the predictions reveal major differences and point towards a degradation of growing conditions (Figure 4, I-III). This pattern, with substantial differences between climate-change scenarios from 2050 onwards, was also shown by Thrippleton et al. (2020), in a similar study carried out in Switzerland.

Taking a closer look at the different stand development scenarios reveals that the differences between these are greater (appr. $50 \mathrm{~m}^{3 *} \mathrm{ha}^{-1}$ ) than those between the climate scenarios (appr. $25 \mathrm{~m}^{3 *} \mathrm{ha}^{-1}$ ). This shows the great advantages of mixed-tree forest stands for climate change mitigation. While the predictions, which are based only on those species that are currently present, show a negative growth pattern (Figure 4, I), allowing natural regeneration of deciduous tree species can stabilize growing stock (Figure 4, II). Developing mixed forests with a high proportion of thermophilus species, above all $Q$. petraea, can foster stable forest stands and sustainable yield. This finding is in line with Steckel et al. (2020), who stated that mixing of $P$. sylvestris and oak species (Q. robur, Q. petraea) can play a considerable role in creating climate-smart forests. The necessity for actively converting forests became even more apparent in view of large outbreaks of bark beetle and defoliating insects, which can trigger abrupt ecosystem changes (Campbell et al., 2009). This risk is especially high in anthropogenic, pure P. abies stands at lower elevations (e.g. Lévesque et al. (2013); Krejza et al. (2020)). Thus the stand development scenario that involves planting climatically suitable tree species (Figure 4, III) will significantly reduce the risk of abrupt changes in forest productivity and other forest ecosystem services. 


\subsection{Supra-regional embedding and international relevance}

In 2020, the Department of Forest Planning of the Office of the Tyrolean Government launched the initiative 'climate adapted mountain forests Tyrol' (Ziegner, 2020). The present study contributes to the scientific basis of the management advice and activities promoted by this initiative. In addition, the study also addresses the Climate Smart Forestry Policy (Kauppi et al., 2018) of the European Union, which consists of three pillars: (i) reduction and sequestration of greenhouse gases; (ii) resilience; (iii) adaptation to change, and the sustainable increase of productivity and welfare. The results presented here directly contribute to the improvement of resilience and adaptation of forests to climate change, and therefore foster stable forest stands and sustainable yield.

\section{Conclusion}

The modelling approach discussed here can be used to assess the impacts of climate change on forest growth at selected sites, and therefore to support decision making at all levels, from forest owners to provincial forest authorities. Target groups are all parties interested in forest ecology and management. Through a set of best-practice recommendations, awareness raising can also reach stakeholder groups beyond the forest sector - in nature conservation, natural hazard protection or regional planning, for example.

The forest stand investigated in this research indicates significant climate-sensitivity, with different reactions by different tree species. Among the tree species present, Norway spruce (Picea abies) and European larch (Larix decidua) are not recommended for drought-prone mountain forests at lower elevations similar to the study site. European beech (Fagus sylvatica), common oak (Quercus robur) and large-leaved lime (Tilia platyphyllos) turned out to be unsuitable under future climate conditions at the site. Scots pine (Pinus sylvestris) continues to be an important species and ensures continuity of the forest cover at the study site. The results seem to be transferable to comparable sites that have artificial Scots pine forests, which are frequent in alpine valleys at low elevation. Considering the high growth potential of sessile oak (Quercus petraea) and small-leaved lime (Tilia cordata), a shift towards mixed forest in which oak dominates would be desirable. Therefore, the potential natural vegetation type under current climate conditions is not always appropriate as a silvicultural objective for future stand composition. To support decision making, development objectives based on the characteristics of specific forest sites must be provided for the total area of forested land.

It has been demonstrated that mixed forest stands that include broadleaved species are necessary to increase the resilience and adapt managed forests to climate change. With active silvicultural measures such as assisted migration through planting thermophilus species, negative effects of climate change could be diminished.

\section{Supplements}

Supplemental information is available at: https://github.com/simonalois/cliffs 


\section{References}

Allen, C., D. Breshears \& N. McDowell (2015), On underestimation of global vulnerability to tree mortality and forest die-off from hotter drought in the Anthropocene. Ecosphere Nr. 6, p. art129; 1-55, 10.1890/ES15-00203.1.

Allen, C. D., A. K. Macalady, H. Chenchouni, D. Bachelet, N. McDowell, M. Vennetier, T. Kitzberger, A. Rigling, D. D. Breshears, E. H. Hogg, P. Gonzalez, R. Fensham, Z. Zhang, J. Castro, N. Demidova, J.-H. Lim, G. Allard, S. W. Running, A. Semerci \& N. Cobb (2010), A global overview of drought and heat-induced tree mortality reveals emerging climate change risks for forests. Forest Ecology and Management Nr. 259(4), p. 660-684, https://doi.org/10.1016/j.foreco.2009.09.001.

Arbeitskreis Standortskartierung (2003), Forstliche Standortsaufnahme. IHW-Verlag, Eching, Germany.

Assmann, E. \& F. Franz (1963), Vorläufige Fichten-Ertragstafel für Bayern 1963. Institut für Ertragskunde der Forstlichen Forschungsanstalt München, Munich, GER.

Auer, I., U. Foelsche, R. Böhm, B. Chimani, L. Haimberger, H. Kerschner, K. A. Koinig, K. Nicolussi \& C. Spötl (2014), Vergangene Klimaänderungen in Österreich. In: (APCC), A. P. o. C. C. (Hrsg.). .): Österreichischer Sachstandsbericht Klimawandel 2014 (AAR14). Vienna, Austria, Verlag der Österreichischen Akademie der Wissenschaften.

Bengtsson, H. (2020), matrixStats: Functions that Apply to Rows and Columns of Matrices (and to Vectors).

Berger, F., L. Dorren, K. Kleemayer, B. Maier, S. Planinsek, C. Bigot, F. Bourrier, O. Jancke, D. Toe \& C. G. (2013), Eco-Engineering and Protection Forests Against Rockfalls and Snow Avalanches. In: Cerbu, G., Hanewinkler, M. \& Gerosa, G. (Hrsg.). Management Strategies to Adapt Alpine Space Forests to Climate Change Risks, Intech Open.

BFW (2019), Zwischenauswertung der Waldinventur 2016/18. BFW Praxisinformation Vienna, AT, Bundesforschungszentrum für Wald. Nr. 50.

Bigler, C., O. U. Bräker, H. Bugmann, M. Dobbertin \& A. Rigling (2006), Drought as an Inciting Mortality Factor in Scots Pine Stands of the Valais, Switzerland. Ecosystems Nr. 9(3), p. 330-343, 10.1007/s10021-005-0126-2.

Blume, H. P., G. W. Brümmer, R. Horn, E. Kandeler, I. Kögel-Knabner, R. Kretzschmar, K. Stahr \& B.-M. Wilke (2009), Scheffer/Schachtschabel: Lehrbuch der Bodenkunde. Spektrum Akademischer Verlag Heidelberg, Germany.

BMNT (2018), Österreichische Waldstrategie 2020+, Bundesministerium für Nachhaltigkeit und Tourismus.

Bugmann, H. (1996), A Simplified Forest Model to Study Species Composition Along Climate Gradients. Ecology Nr. 77, 10.2307/2265700.

Bugmann, H. (2001), A Review of Forest Gap Models. Climatic Change Nr. 51(3), p. 259-305, 10.1023/A:1012525626267.

Campbell, E., S. C. Saunders, D. Coates, D. Meidinger, A. MacKinnon, G. O’Neil, D. MacKillop \& C. DeLong (2009), Ecological resilience and complexity: a theoretical framework for understanding and managing British Columbia's forest ecosystems in a changing climate. Technical Report 055. Victoria, B.C., B.C. Min. For. Range, For. Sci. Prog. . Nr. 55.

Duncan, T. L. (2020), XML: Tools for Parsing and Generating XML Within R and S-Plus.

Eckmüllner, O. (2004), Empfohlene Ertragstafeln für Nord- und Osttirol. Amt der Tiroler Landesregierung, Abt. Forstplanung, Innsburck, AT.

Forest Act (1975), Forstgesetz. Government, A. Vienna, AT. Nr. StF: BGBl. Nr. 440/1975; NR: GP XIII RV 1266 AB 1677 S. 150. BR: 1392 AB 1425, p. 344.

Forest Ecology Group (2019), ForClim Documentation, Release 4.0. Zürich, CH, ETH Zürich. 
Forest Site Classification Tyrol (2018), Waldtypisierung Tirol. Planning, D. o. F., Office of the Tyrolean government.

Fuhrer, J., M. Beniston, A. Fischlin, C. Frei, S. Goyette, K. Jasper \& C. Pfister (2006), Climate risks and their impact on agriculture and forests in Switzerland. Climatic Change Nr. 79, p. 79-102.

Guisan, A., W. Thuiller \& N. E. Zimmermann (2017), Habitat Suitability and Distribution Models: With Applications in R. Cambridge University Press, Cambridge.

Hartig, T. (1847), Vergleichende Untersuchungen über den Ertrag der Rothbuche im Hoch- und Pflanz-Walde, im Mittel- und Niederwald-Betriebe nebst Anleitung zu vergleichenden Ertragsforschungen. Förstner, Berlin, GER.

Hölscher, D., O. Koch, S. Korn \& C. Leuschner (2005), Sap flux of five co-occurring tree species in a temperate broad-leaved forest during seasonal soil drought. Trees Nr. 19, p. 628-637, 10.1007/s00468-005-0426-3.

Huber, N. (2019), Towards robust projections of future forest dynamics: why there is no silver bullet to cope with complexity. Thesis, ETH Zurich.

Huber, N., H. Bugmann \& V. Lafond (2020), Capturing ecological processes in dynamic forest models: why there is no silver bullet to cope with complexity. Ecosphere Nr. 11(5), https://doi.org/10.1002/ecs2.3109.

IPCC (2014), Climate Change 2014: Synthesis Report. Contribution of Working Groups I, II and III to the Fifth Assessment Report of the Intergovernmental Panel on Climate Change. Pachauri, R. K. \& Meyer, L. A. Geneva, CH, p. 151.

Irauschek, F., I. Barka, H. Bugmann, B. Courbaud, C. Elkin, T. Hlásny, M. Klopcic, M. Mina, W. Rammer \& M. J. Lexer (2021), Evaluating five forest models using multi-decadal inventory data from mountain forests. Ecological Modelling Nr. 445, p. 109493, https://doi.org/10.1016/j.ecolmodel.2021.109493.

IUSS Working Group WRB (2014), World Reference Base for Soil Resources 2014: international soil classification system for naming soils and creating legends for soil maps. FAO, Rome, IT.

Jump, A. S., J. M. Hunt \& J. Penuelas (2006), Rapid climate change-related growth decline at the southern range edge of Fagus sylvatica. Global Change Biology Nr. 12(11), p. 2163-2174.

Kauppi, P., H. Hanewinkel, T. Lundmark, L. Hetemäki, H. Peltola \& A. Trasobares (2018), Climate Smart Forestry in Europe. Joensuu, FIN, European Forest Institute.

Krakau, U.-K., M. Liesebach, T. Aronen, M.-A. Lelu-Walter \& V. Schneck (2013), Scots Pine (Pinus sylvestris L.). In: Pâques, L. E. (Hrsg.). Forest Tree Breeding in Europe, Springer Netherlands, p. 267-323.

Krejza, J., E. Cienciala, J. Světlík, M. Bellan, E. Noyer, P. Horáček, P. Štěpánek \& M. V. Marek (2020), Evidence of climate-induced stress of Norway spruce along elevation gradient preceding the current dieback in Central Europe. Trees, 10.1007/s00468-020-02022-6.

Le Quéré, C., R. M. Andrew, P. Friedlingstein, S. Sitch, J. Hauck, J. Pongratz, P. A. Pickers, J. I. Korsbakken, G. P. Peters, J. G. Canadell, A. Arneth, V. K. Arora, L. Barbero, A. Bastos, L. Bopp, F. Chevallier, L. P. Chini, P. Ciais, S. C. Doney, T. Gkritzalis, D. S. Goll, I. Harris, V. Haverd, F. M. Hoffman, M. Hoppema, R. A. Houghton, G. Hurtt, T. Ilyina, A. K. Jain, T. Johannessen, C. D. Jones, E. Kato, R. F. Keeling, K. K. Goldewijk, P. Landschützer, N. Lefèvre, S. Lienert, Z. Liu, D. Lombardozzi, N. Metzl, D. R. Munro, J. E. M. S. Nabel, S. Nakaoka, C. Neill, A. Olsen, T. Ono, P. Patra, A. Peregon, W. Peters, P. Peylin, B. Pfeil, D. Pierrot, B. Poulter, G. Rehder, L. Resplandy, E. Robertson, M. Rocher, C. Rödenbeck, U. Schuster, J. Schwinger, R. Séférian, I. Skjelvan, T. Steinhoff, A. Sutton, P. P. Tans, H. Tian, B. Tilbrook, F. N. Tubiello, I. T. van der Laan-Luijkx, G. R. van der Werf, N. Viovy, A. P. Walker, A. J. Wiltshire, R. Wright, S. Zaehle \& B. Zheng (2018), Global Carbon Budget 2018. Earth Syst. Sci. Data Nr. 10(4), p. 2141-2194, 10.5194/essd-10-21412018. 
Leuschner, C. (2020), Drought response of European beech (Fagus sylvatica L.) -A review.

Perspectives in Plant Ecology, Evolution and Systematics Nr. 47, p. 125576, https://doi.org/10.1016/j.ppees.2020.125576.

Lévesque, M., M. Saurer, R. Siegwolf, B. Eilmann, P. Brang, H. Bugmann \& A. Rigling (2013), Drought response of five conifer species under contrasting water availability suggests high vulnerability of Norway spruce and European larch. Global Change Biology Nr. 19(10), p. 31843199, https://doi.org/10.1111/gcb.12268.

Linkevičius, E., J. G. Borges, M. Doyle, H. Pülzl, E.-M. Nordström, H. Vacik, V. Brukas, P. Biber, M. Teder, P. Kaimre, M. Synek \& J. Garcia-Gonzalo (2019), Linking forest policy issues and decision support tools in Europe. Forest Policy and Economics Nr. 103, p. 4-16, https://doi.org/10.1016/j.forpol.2018.05.014.

Lorey, T. (1878), Die mittlere Bestandeshöhe. Allgemeine Forst- und Jagdzeitung Nr. 54, p. 149-155. Monserud, R. A. \& H. Sterba (1999), Modeling individual tree mortality for Austrian forest species. Forest Ecology and Management Nr. 113(2), p. 109-123, https://doi.org/10.1016/S03781127(98)00419-8.

Nagel, T. A., S. Miroslav, T. Rugani \& J. Diaci (2010), Gap regeneration and replacement patterns in an old-growth Fagus-Abies forest of Bosnia-Herzegovina. Plant Ecology Nr. 208, p. 307-318.

Nestroy, O., G. Aust, W. Blum, M. Englisch, H. Hager, E. Herzberger, W. Kilian, P. Nelhiebel, G. Ortner, E. Pecina, A. Pehamberger, W. Schneider \& J. Wagner (2000, 2011), Systematische Gliederung der Böden Österreichs. Österreichische Bodensystematik 2000 in der revidierten Fassung von 2011. Mitteilungen der Österreichischen Bodenkundlichen Gesellschaft Nr. 79.

Nüst, D., C. Granell, B. Hofer, M. Konkol, F. Ostermann, R. Sileryte \& V. Cerutti (2018), Reproducible research and GIScience: An evaluation using AGILE conference papers. PeerJ Nr. 6, p. e5072, $10.7717 /$ peerj.5072.

Obojes, N., A. Meurer, C. Newesely, E. Tasser, W. Oberhuber, S. Mayr \& U. Tappeiner (2018), Water stress limits transpiration and growth of European larch up to the lower subalpine belt in an inneralpine dry valley. New Phytologist Nr. 220(2), 10.1111/nph.15348.

ÖKS15 (2016), Klimaszenarien für Österreich - Daten - Methoden - Klimaanalyse. Vienna, AT, Ministerium für ein Lebenswertes Österreich.

Pecchi, M., M. Marchi, V. Burton, F. Giannetti, M. Moriondo, I. Bernetti, M. Bindi \& G. Chirici (2019), Species distribution modelling to support forest management. A literature review.

Ecological Modelling Nr. 411, p. 108817, https://doi.org/10.1016/j.ecolmodel.2019.108817.

Pierce, D. (2017), ncdf4: Interface to Unidata netCDF (Version 4 or Earlier) Format Data.

Ponton, S., J.-L. Dupouey, B. Nathalie \& E. Dreyer (2002), Comparison of water-use efficiency of seedlings from two sympatric oak species: Genotype x environment interactions. Tree physiology Nr. 22, p. 413-22, 10.1093/treephys/22.6.413.

Prietzel, J. \& D. Christophel (2014), Organic carbon stock in forest soils of the German Alps. Geoderma Nr. 221-222, p. 28-39.

R Core Team (2019), R: A language and environment for statistical computing. R Foundation for Statistical Computing, Vienna, AT.

Rasche, L., L. Fahse, A. Zingg \& H. Bugmann (2011), Getting a virtual forester fit for the challenge of climatic change. Journal of Applied Ecology Nr. 48, p. 1174-1186, 10.1111/j.1365-

2664.2011.02014.x.

Remund, J. \& S. Augustin (2015), Zustand und Entwicklung der Trockenheit in Schweizer Wäldern. Schweizerische Zeitschrift fur Forstwesen Nr. 166, p. 352-360.

Röhle, H. (2004), Wuchsmodelle und Umweltfaktoren - Möglichkeiten und Grenzen der forstlichen Modellierung. Forst und Holz Nr. 59, p. 480-484.

Sarkar, D. (2008), Lattice: Multivariate Data Visualization with R. Springer, NY, USA.

Schuldt, B., A. Buras, M. Arend, Y. Vitasse, C. Beierkuhnlein, A. Damm, M. Gharun, T. E. E. Grams, M. Hauck, P. Hajek, H. Hartmann, E. Hiltbrunner, G. Hoch, M. Holloway-Phillips, C. Körner, E. 
Larysch, T. Lübbe, D. B. Nelson, A. Rammig, A. Rigling, L. Rose, N. K. Ruehr, K. Schumann, F. Weiser, C. Werner, T. Wohlgemuth, C. S. Zang \& A. Kahmen (2020), A first assessment of the impact of the extreme 2018 summer drought on Central European forests. Basic and Applied Ecology Nr. 45, p. 86-103, https://doi.org/10.1016/j.baae.2020.04.003.

Schwappach, A. (1890), Wachstum und Ertrag normaler Fichtenbestände. Springer, Berlin, GER. Seidl, R., W. Rammer \& M. Lexer (2011), Climate change vulnerability of sustainable forest managemetn in the Eastern Alps. Climatic Change Nr. 106, p. 225-254.

Seidl, R., D. Thom, M. Kautz, D. Martin-Benito, M. Peltoniemi, G. Vacchiano, J. Wild, D. Ascoli, M. Petr, J. Honkaniemi, M. J. Lexer, V. Trotsiuk, P. Mairota, M. Svoboda, M. Fabrika, T. A. Nagel \& C. P. O. Reyer (2017), Forest disturbances under climate change. Nature Climate Change Nr. 7(6), p. 395-402, 10.1038/nclimate3303.

Simon, A., M. Wilhelmy, R. Klosterhuber, E. Cocuzza, C. Geitner \& K. Katzensteiner (2021), A system for classifying subsolum geological substrates as a basis for describing soil formation. Catena Nr. 198, p. 105026, https://doi.org/10.1016/j.catena.2020.105026.

Spiecker, H. (2000), Growth of Norway spruce (Picea abies [L.] Karst.) under changing environmental conditions in Europe. EFI Proceedings. Klimo, E., Hager, H. \& Jirí, K., European Forest Institute. Nr. 33, p. 11-26.

Steckel, M., M. del Río, M. Heym, J. Aldea, K. Bielak, G. Brazaitis, J. Černý, L. Coll, C. Collet, M. Ehbrecht, A. Jansons, A. Nothdurft, M. Pach, M. Pardos, Q. Ponette, D. O. J. Reventlow, R. Sitko, M. Svoboda, P. Vallet, B. Wolff \& H. Pretzsch (2020), Species mixing reduces drought susceptibility of Scots pine (Pinus sylvestris L.) and oak (Quercus robur L., Quercus petraea (Matt.) Liebl.) - Site water supply and fertility modify the mixing effect. Forest Ecology and Management Nr. 461, p. 117908, https://doi.org/10.1016/j.foreco.2020.117908.

Sturrock, R. N., S. J. Frankel, A. V. Brown, P. E. Hennon, J. T. Kliejunas, K. J. Lewis, J. J. Worrall \& A. J. Woods (2011), Climate change and forest diseases. Plant Pathology Nr. 60, p. 133-149.

Thrippleton, T., F. Lüscher \& H. Bugmann (2020), Climate change impacts across a large forest enterprise in the Northern Pre-Alps: dynamic forest modelling as a tool for decision support European Journal of Forest Research Nr. 139, p. 483-498.

Thurm, E. A., S. Brandl, H. Fischer, K. H. Mellert, T. Mette, B. Reger \& W. Weis (2020), Nadelbäume im Trockenstress. LWF-aktuell Nr. 3, p. 24-27.

Vacik, H. \& M. J. Lexer (2014), Past, current and future drivers for the development of decision support systems in forest management. Scandinavian Journal of Forest Research Nr. 29(sup1), p. 2-19, 10.1080/02827581.2013.830768.

Vivin, P., G. Aussenac \& G. Levy (1993), Differences in drought resistance among 3 deciduous oak speciesgrown in large boxes. Annales des sciences forestières Nr. 50(3), p. 221-233.

Wang, F., D. Israel, J.-A. Ramírez-Valiente, D. Sánchez-Gómez, I. Aranda, P. J. Aphalo \& T. M. Robson (2020), Seedlings from marginal and core populations of European beech (Fagus sylvatica L.) respond differently to imposed drought and shade. Trees, 10.1007/s00468-020-02011-9. Weisse, W. (1880), Ertragstafeln für die Kiefer. Springer, Berlin, GER.

ZAMG (2015), Das Klima von Tirol - Südtirol - Belluno. Zentralanstalt für Meteorologie und Geodynamik, Abteilung Brand- und Zivilschutz - Autonome Provinz Bozen, Agenzia Regionale per la Prevenzione e Protezione Ambientale desl Vento (ARPAV).

Ziegner, K. (2020), Klimafitter Bergwald Tirol. Innsbruck, AT, Department of Forest Planning. 